\title{
Blood urea nitrogen to serum albumin ratio independently predicts mortality and severity of community-acquired pneumonia
}

This article was published in the following Dove Press journal:

International Journal of General Medicine

II July 2012

Number of times this article has been viewed

\section{Motoi Ugajin \\ Kenichi Yamaki \\ Natsuko Iwamura \\ Takeo Yagi \\ Takayuki Asano}

Department of Respiratory Medicine, Ichinomiya-Nishi Hospital, Ichinomiya City, Aichi Prefecture, Japan
Correspondence: Motoi Ugajin Department of Respiratory Medicine, Ichinomiya-Nishi Hospital, I Hira, Kaimei, Ichinomiya City 494-000 I, Japan Tel +8I5 86480077

Fax +8I5 86480038

Email ugarin200I@yahoo.co.jp
Background: Early studies of community-acquired pneumonia showed that nonsurvivors had higher blood urea nitrogen levels and lower serum albumin levels than survivors. Therefore, elevation of the blood urea nitrogen to serum albumin $(\mathrm{B} / \mathrm{A})$ ratio may identify patients with community-acquired pneumonia who are becoming critically ill. This study investigated the correlation between commonly used laboratory markers, in particular the B/A ratio, and clinical outcomes of community-acquired pneumonia.

Methods: This observational study was performed in consecutive patients with communityacquired pneumonia admitted to our hospital over a period of one year. Blood counts, commonly used laboratory markers, microbiological tests, and calculation of Pneumonia Severity Index (PSI) and CURB-65 were done on admission. The endpoints were mortality within 28 days of admission and requirement for intensive care.

Results: One hundred and seventy-five patients with community-acquired pneumonia were enrolled. Nineteen patients died within 28 days of admission and 29 patients required intensive care. Using multivariate analysis, independent factors associated with mortality were the requirement for intensive care (odds ratio [OR] 14.96, 95\% confidence interval [CI] 3.73-60.03, $P<0.001$ ), PSI class (OR 3.55, 95\% CI 1.08-11.66, $P=0.037$ ), and B/A ratio (OR $1.10,95 \%$ CI 1.01-1.20, $P=0.037$ ). Similarly, independent factors associated with need for intensive care were PSI class (OR 5.35, 95\% CI 1.90-15.06, $P=0.002$ ), CURB-65 (OR 2.37, 95\% CI $1.26-4.45, P=0.007$ ), and $\mathrm{B} / \mathrm{A}$ ratio (OR $1.27,95 \% \mathrm{CI} 1.09-1.47, P=0.002)$.

Conclusion: The $\mathrm{B} / \mathrm{A}$ ratio is a simple but independent predictor of mortality and severity of community-acquired pneumonia.

Keywords: blood urea nitrogen to serum albumin ratio, Pneumonia Severity Index, CURB-65, community-acquired pneumonia, mortality, severity

\section{Introduction}

Community-acquired pneumonia (CAP) is a serious illness and a common cause of death. Many clinicians are concerned about the severity of CAP and its associated mortality. The Pneumonia Patients Outcome Research Team score was introduced in 1997 to assess the severity of CAP after a study including more than 50,000 patients. ${ }^{1}$ Established by the American Thoracic Society/Infectious Diseases Society of America, this scoring system is called the Pneumonia Severity Index (PSI) and is the recommended severity scoring system for CAP. More simple severity scores for CAP, such as CURB-65, have also been documented. ${ }^{2}$ CURB-65 is a five-point scoring system for CAP, recommended by the British Thoracic Society, and includes confusion, 
urea $>7 \mathrm{mmol} / \mathrm{L}(20 \mathrm{mg} / \mathrm{dL})$, respiratory rate $\geq 30$ breaths per minute, low blood pressure, and age $\geq 65$ years. However, these scoring systems may be affected by subjectivity on the part of the individual clinician. For example, it is often difficult for clinicians to evaluate the mental status of patients with CAP who have dementia or those of advanced age, so the severity score may vary from clinician to clinician. ${ }^{3,4}$

In contrast, certain serum biomarkers have been reported to predict mortality and to indicate the severity of CAP. These include inflammatory biomarkers, such as C-reactive protein $^{5-7}$ and procalcitonin, ${ }^{8-11}$ both of which are correlated with mortality and severity of CAP. Of the commonly used laboratory biomarkers, earlier studies showed that nonsurvivors of CAP had higher blood urea nitrogen levels ${ }^{2,12,13}$ and lower serum albumin levels ${ }^{2,14,15}$ than survivors. Therefore, we hypothesized that the blood urea nitrogen to serum albumin (B/A) ratio may be elevated in critically ill patients with CAP and be correlated with mortality or severity of CAP. In this single-center, prospective, observational study, we investigated the relationship between commonly used laboratory markers, especially the $\mathrm{B} / \mathrm{A}$ ratio, and the clinical outcomes of CAP.

\section{Materials and methods}

\section{Patients}

Patients with CAP consecutively admitted to IchinomiyaNishi Hospital (a 400-bed teaching hospital, Ichinomiya City, Aichi, Japan) from January to December 2011 were enrolled in this study. CAP was diagnosed in patients aged $\geq 18$ years who were admitted from the community, did not have any antibiotic exposure during the 14 days prior to enrollment, presented with a new radiographic infiltrate, and showed at least two compatible clinical symptoms (eg, body temperature $>38^{\circ} \mathrm{C}$, productive cough, chest pain, shortness of breath, crackles on auscultation). Patients were excluded if they had been hospitalized in the 90 days before the start of the study, if they were chronically immunosuppressed (ie, chemotherapy, human immunodeficiency virus infection, therapy with $\geq 20 \mathrm{mg}$ prednisone or equivalent, other immunosuppressive therapy), if they had advanced liver disease, or if they had received hemodialysis or had a serum creatinine level $\geq 1.5 \mathrm{mg} / \mathrm{dL}$ due to chronic kidney disease. The study was approved by the ethics committee of our hospital, and informed consent was obtained from all patients according to the hospital's guidelines.

\section{Methods and endpoints}

Venous blood samples were obtained from the patients on admission. Measurements of blood counts and serum biochemical markers (ie, blood urea nitrogen, albumin, glucose, creatinine, sodium, C-reactive protein) were performed immediately after sampling. Blood urea nitrogen was measured using an enzymatic method with urease and glutamate dehydrogenase (Shino-Test Corporation, Tokyo, Japan). Serum albumin and C-reactive protein levels were measured using the bromocresol green method (Shino-Test Corporation) and latex coagulating nephelometric assay (Nittobo Medical, Tokyo, Japan), respectively. Other biochemical markers were assayed using standard methods.

PSI $^{1}$ and CURB- $65^{2}$ were calculated for all participants on admission. Microbiological sputum examination and urinary antigen tests for Streptococcus pneumoniae (Binax Inc, Portland, ME) and Legionella pneumophila serogroup 1 (Binax Inc) were done on admission. The choice of antibiotic regimen was made according to the guideline for CAP proposed by the Japanese Respiratory Society. The endpoints of this study were mortality within 28 days of admission and requirement for intensive care, defined as a need for mechanical ventilation or vasopressor therapy for septic shock.

\section{Statistical analysis}

The data are expressed as the number or median (25th-75th range). Differences between the two groups were tested using the nonparametric Mann-Whitney U test for continuous variables and Fisher's Exact test for categorical variables. Multiple logistic regression analysis was performed to assess the independent association between each factor and mortality within 28 days of admission or need for intensive care. The results are expressed as odds ratios (OR) and $95 \%$ confidence intervals (CI). Variables significantly associated with mortality or need for intensive care at the 0.20 level in univariate analysis were considered in a multivariate backward analysis. Analysis of a receiver-operating characteristic curve was performed to identify the best cutoff value to predict mortality and need for intensive care. A probability value $<0.05$ was considered to be statistically significant.

\section{Results \\ Patient population}

During the study period, a total of 213 patients with CAP were admitted. Of these patients, 38 were excluded because of hospitalization in the previous 90 days $(n=25)$, chronic 
kidney disease $(n=9)$, and immunosuppression $(n=4)$. Finally, 175 patients were enrolled in the study. Causative pathogens were detected in 68 patients (38.9\%) and are listed in Table 1 . The most frequently detected pathogen was Streptococcus pneumoniae $(\mathrm{n}=25,14.3 \%)$. Patient characteristics are shown in Table 2 . Nineteen patients (10.9\%) died within 28 days of admission and 29 patients (16.6\%) needed intensive care. The cause of mortality was respiratory failure in all deceased patients.

\section{Factors associated with mortality}

A comparison of characteristics between deceased and surviving patients is shown in Table 3. Deceased patients were more likely to be of advanced age, to require intensive care, to be categorized into a high PSI class, and to have a high CURB-65 score. Of the commonly used laboratory biomarkers, the deceased patients had higher serum sodium and blood urea nitrogen levels, a higher B/A ratio, and lower serum albumin levels than did surviving patients. Conversely, the serum C-reactive protein level did not differ significantly between the two groups. The results of multivariate analysis for mortality are shown in Table 4. Factors independently associated with mortality were need for intensive care (OR 14.96, 95\% CI 3.73-60.03, $P<0.001$ ), PSI class (OR 3.55, 95\% CI 1.08-11.66, $P=0.037$ ), and $\mathrm{B} / \mathrm{A}$ ratio (OR 1.10, 95\% CI 1.01-1.20, $P=0.037)$. Conversely, there was no significant association between CURB-65 and mortality (OR $1.83,95 \%$ CI $0.96-3.50, P=0.067$ ).

\section{Factors associated with need for intensive care}

A comparison of characteristics for patients with and without intensive care is shown in Table 5. Patients who required

Table I Causative pathogens

\begin{tabular}{ll}
\hline Micro-organism & $\mathbf{n}$ \\
\hline Streptococcus pneumoniae & $25(\mathrm{I} 4.3)$ \\
Klebsiella pneumoniae & $\mathrm{II}(6.3)$ \\
Pseudomonas aeruginosa & $9(5.1)$ \\
Staphylococcus species & $7(4.0)$ \\
MRSA & $6(3.4)$ \\
Haemophilus influenzae & $4(2.3)$ \\
Escherichia coli & $2(1.1)$ \\
Proteus mirabilis & $\mathrm{I}(0.6)$ \\
Legionella pneumophila & $\mathrm{I}(0.6)$ \\
Moraxella catarrhalis & $\mathrm{I}(0.6)$ \\
Stenotrophomonas maltophilia & $\mathrm{I}(0.6)$ \\
Unknown & $\mathrm{I} 07(6 \mathrm{I} . \mathrm{I})$ \\
\hline
\end{tabular}

Note: Data are expressed as number (\%).

Abbreviation: MRSA, methicillin-resistant Staphylococcus aureus.
Table 2 Baseline characteristics of enrolled patients

\begin{tabular}{ll}
\hline Characteristics & Values \\
\hline Total & 175 \\
Age, years & $81(74-87)$ \\
Male patients & $98(56.0)$ \\
Identification of pathogen & $68(38.9)$ \\
Death within 28 days & $19(10.9)$ \\
Intensive care requirement & $29(16.6)$ \\
Coexisting illnesses & \\
Chronic lung disease & $20(11.4)$ \\
Diabetes mellitus & $30(17.1)$ \\
Heart failure & $29(16.6)$ \\
Neoplastic disease & $3(1.7)$ \\
PSI class & \\
I & $7(4.0)$ \\
2 & $12(6.9)$ \\
3 & $4 I(23.4)$ \\
4 & $77(44.0)$ \\
5 & $38(21.7)$ \\
CURB-65 & \\
0-I & $45(25.7)$ \\
2 & $59(33.7)$ \\
$>3$ & $71(40.6)$ \\
Leukocyte count, I09 cells/L & $10.7(7.7-13.2)$ \\
Hematocrit, \% & $37.4(34.4-40.5)$ \\
C-reactive protein, mg/dL & $12.35(6.30-18.80)$ \\
Sodium, mEq/L & $139(137-142)$ \\
Glucose, mg/dL & $130(107-161)$ \\
Creatinine, mg/dL & $0.76(0.62-1.05)$ \\
Blood urea nitrogen, mg/dL & $20.0(14.7-29.1)$ \\
Albumin, g/dL & $3.7(3.3-4.0)$ \\
B/A ratio, mg/g & $5.61(3.90-8.4 I)$ \\
\hline
\end{tabular}

Note: Data are expressed as number (\%) or median (25th-75th percentile). Abbreviations: PSI, Pneumonia Severity Index; B/A ratio, blood urea nitrogen to serum albumin ratio.

intensive care were more likely to be of advanced age, to have coexisting illness, to be categorized into a high PSI class, and to have a high CURB-65 score. Of the commonly used laboratory biomarkers, patients who required intensive care had higher serum sodium and blood urea nitrogen levels, a higher $\mathrm{B} / \mathrm{A}$ ratio, and a lower serum albumin level than those who did not require intensive care. Conversely, the serum C-reactive protein level did not differ significantly between the two groups. The results of multivariate analysis of need for intensive care are presented in Table 6. Independent factors associated with need for intensive care were PSI class (OR 5.35, 95\% CI 1.90-15.06, $P=0.002$ ), CURB-65 (OR $2.37,95 \%$ CI $1.26-4.45, P=0.007)$, and $\mathrm{B} / \mathrm{A}$ ratio (OR 1.27, $95 \%$ CI $1.09-1.47, P=0.002)$.

\section{Optimal cutoff value of $B / A$ ratio}

The receiver-operating characteristic curve for predicting mortality within 28 days from admission is shown in Figure 1. 
Table 3 Comparison of characteristics between deceased and surviving patients with CAP

\begin{tabular}{|c|c|c|c|}
\hline & Deceased $(n=19)$ & Surviving $(n=156)$ & $P$ value \\
\hline Age, years & $84(81.5-92.5)$ & 80 (72.75-87) & 0.013 \\
\hline Male patients & $7(36.8)$ & 91 (58.3) & 0.089 \\
\hline Identification of pathogen & $10(52.6)$ & $58(37.2)$ & 0.218 \\
\hline Intensive care requirement & $15(78.9)$ & $14(9.0)$ & $<0.001$ \\
\hline Coexisting illness & $12(63.2)$ & $62(39.7)$ & 0.083 \\
\hline PSI class & $5(4.5-5)$ & $4(3-4)$ & $<0.001$ \\
\hline CURB-65 & $4(3-4)$ & $2(I-3)$ & $<0.001$ \\
\hline Leukocyte count, $10^{9}$ cells $/ \mathrm{L}$ & $9.9(7.7-15.3)$ & II.I (7.7-I3.2) & 0.685 \\
\hline Hematocrit, \% & 37.7 (33.7-39.7) & $37.4(34.6-40.5)$ & 0.863 \\
\hline C-reactive protein, $\mathrm{mg} / \mathrm{dL}$ & $12.86(7.05-23.52)$ & $12.18(6.03-18.70)$ & 0.446 \\
\hline Sodium, $\mathrm{mEq} / \mathrm{L}$ & $143(137.5-156)$ & $139(|36-14|)$ & 0.008 \\
\hline Glucose, mg/dL & $14 \mid(108-166)$ & $130(107-158.5)$ & 0.725 \\
\hline Creatinine, $\mathrm{mg} / \mathrm{dL}$ & $0.88(0.63-1.40)$ & $0.75(0.62-0.99)$ & 0.316 \\
\hline Blood urea nitrogen, $\mathrm{mg} / \mathrm{dL}$ & $39.8(25.4-72.6)$ & $18.9(14.3-26.3)$ & 0.001 \\
\hline Albumin, g/dL & $3.2(3.1-3.5)$ & $3.7(3.4-4.0)$ & 0.001 \\
\hline $\mathrm{B} / \mathrm{A}$ ratio, $\mathrm{mg} / \mathrm{g}$ & $12.77(8.19-20.53)$ & $5.26(3.84-7.46)$ & $<0.001$ \\
\hline
\end{tabular}

Note: Data are expressed as number (\%) or median (25th-75th range).

Abbreviations: CAP, community acquired pneumonia; PSI, Pneumonia Severity Index; B/A ratio, blood urea nitrogen to serum albumin ratio.

The area under the curve (AUC) was 0.83 for $\mathrm{B} / \mathrm{A}$ ratio $(95 \%$ CI $0.73-0.94), 0.82$ for PSI class (95\% CI $0.73-0.91), 0.81$ for CURB-65 (95\% CI 0.71-0.91), and 0.55 for C-reactive protein (95\% CI 0.41-0.69). Similarly, the receiver-operating characteristic curve for predicting need for intensive care is shown in Figure 2. The AUC was 0.86 for the B/A ratio ( $95 \%$ CI $0.79-0.94), 0.86$ for PSI class (95\% CI 0.79-0.93), 0.84 for CURB-65 (95\% CI 0.77-0.91), and 0.58 for C-reactive protein (95\% CI 0.46-0.71). The sensitivities, specificities, and positive and negative predictive values of the $\mathrm{B} / \mathrm{A}$ ratio for mortality and need for intensive care are presented in Table 7. The optimal cutoff value of the B/A ratio for predicting mortality was $12.44 \mathrm{mg} / \mathrm{g}$, with a sensitivity of $57.9 \%$, specificity of $94.5 \%$, a positive predictive value of $57.9 \%$, and a negative predictive value of $94.5 \%$. Similarly, the optimal cutoff value for the $\mathrm{B} / \mathrm{A}$ ratio predicting the need for intensive care was $9.85 \mathrm{mg} / \mathrm{g}$, with a sensitivity of $62.1 \%$,

Table 4 Multivariate analysis for mortality within 28 days from admission

\begin{tabular}{lll}
\hline & OR $(95 \% \mathrm{CI})$ & $\boldsymbol{P}$ value \\
\hline Age & $1.02(0.94-1.12)$ & $0.6 \mathrm{I} 2$ \\
Intensive care requirement & $14.96(3.73-60.03)$ & $<0.00 \mathrm{I}$ \\
PSI class & $3.55(1.08-1 \mathrm{I} .66)$ & 0.037 \\
CURB-65 & $1.83(0.96-3.50)$ & 0.067 \\
Sodium & $1.02(0.96-1.08)$ & $0.62 \mathrm{I}$ \\
Blood urea nitrogen & $1.02(0.99-1.05)$ & 0.098 \\
Albumin & $0.4 \mathrm{I}(0.1 \mathrm{I}-\mathrm{I} .48)$ & 0.176 \\
B/A ratio & $\mathrm{I} .10(\mathrm{I} .0 \mathrm{I}-\mathrm{I} .20)$ & 0.037 \\
\hline
\end{tabular}

Abbreviations: $\mathrm{Cl}$, confidence interval; OR, odds ratio; PSI, Pneumonia Severity Index; B/A ratio, blood urea nitrogen to serum albumin ratio. specificity of $91.8 \%$, a positive predictive value of $60.0 \%$, and a negative predictive value of $92.4 \%$.

\section{Discussion}

In this CAP study, we demonstrated that the $\mathrm{B} / \mathrm{A}$ ratio was an independent risk factor for mortality within 28 days of admission and requirement for intensive care, and that the serum C-reactive protein level on admission had little predictive value regarding the severity or likelihood of mortality from the illness.

Serum albumin plays an important role in maintaining physiological homeostasis, including maintenance of normal colloid osmotic pressure, transport of endogenous compounds, and scavenging of oxidizing agents. ${ }^{16}$ Although malnutrition can decrease serum albumin levels, there is growing evidence that the systemic inflammatory response can have the same effect. ${ }^{17,18} \mathrm{~A}$ study in rats showed that even in well-fed animals, serum albumin concentration and liver albumin mRNA levels were markedly decreased during inflammation. ${ }^{19}$ However, the hydration status of patients should be considered when evaluating the results of blood investigations, because water deficiency develops rapidly and insidiously in patients with pneumonia. ${ }^{20}$ In the dehydrated condition, reabsorption of urea by the kidneys is increased, so elevation of blood urea nitrogen levels is frequently observed. ${ }^{21}$ Therefore, the $\mathrm{B} / \mathrm{A}$ ratio is associated with critical illness. Consistent with our present study, earlier studies have shown that nonsurvivors of CAP have significantly higher blood urea nitrogen levels ${ }^{2,12,13}$ and lower serum albumin levels ${ }^{2,14,15}$ than survivors. According to 
Table 5 Comparison of characteristics between patients with and without intensive care

\begin{tabular}{|c|c|c|c|}
\hline & IC requirement $(n=29)$ & No requirement $(n=146)$ & $P$ value \\
\hline Age, years & $83(82-90)$ & $80(72-87)$ & 0.005 \\
\hline Male patients & $14(48.3)$ & $84(57.5)$ & 0.415 \\
\hline Identification of pathogen & $13(44.8)$ & $55(37.6)$ & 0.533 \\
\hline Coexisting illness & $18(62.0)$ & $56(38.4)$ & 0.023 \\
\hline PSI class & $5(5-5)$ & $4(3-4)$ & $<0.001$ \\
\hline CURB-65 & $3(3-4)$ & $2(I-3)$ & $<0.001$ \\
\hline Leukocyte count, $10^{9}$ cells $/ \mathrm{L}$ & I I.6 (7.7-16.2) & $10.7(7.7-13.1)$ & 0.362 \\
\hline Hematocrit, \% & $36.7(32.0-38.9)$ & $37.5(34.6-40.5)$ & 0.369 \\
\hline C-reactive protein, $\mathrm{mg} / \mathrm{dL}$ & $12.76(7.06-25.76)$ & $12.09(6.11-18.06)$ & 0.152 \\
\hline Sodium, $\mathrm{mEq} / \mathrm{L}$ & $142(138-149)$ & $139(|36-| 4 \mid)$ & 0.004 \\
\hline Glucose, mg/dL & $132(105-178)$ & $130(\mid 07-157)$ & 0.738 \\
\hline Creatinine, $\mathrm{mg} / \mathrm{dL}$ & $0.92(0.63-1.23)$ & $0.73(0.6 \mathrm{I}-0.96)$ & 0.106 \\
\hline Blood urea nitrogen, $\mathrm{mg} / \mathrm{dL}$ & $39.6(26.3-63.3)$ & $18.2(14.0-24.6)$ & $<0.001$ \\
\hline Albumin, g/dL & $3.3(3.0-3.6)$ & $3.8(3.4-4.1)$ & 0.001 \\
\hline $\mathrm{B} / \mathrm{A}$ ratio, $\mathrm{mg} / \mathrm{g}$ & $12.44(8.15-18.09)$ & $5.09(3.57-7.07)$ & $<0.001$ \\
\hline
\end{tabular}

Note: Data are expressed as number (\%) or median (25th-75th range).

Abbreviations: IC, intensive care; PSI, Pneumonia Severity Index; B/A ratio, blood urea nitrogen to serum albumin ratio.

our current study, the $\mathrm{B} / \mathrm{A}$ ratio is more accurate for predicting mortality and severity of CAP than serum albumin or blood urea nitrogen levels alone.

PSI includes patient characteristics, comorbid illnesses, findings of physical examination, radiographic findings, and laboratory results. ${ }^{1}$ Although the PSI has been shown to perform consistently well as a predictor of CAP mortality, it may be complex to calculate and difficult to implement in routine clinical practice. ${ }^{22}$ Therefore, other simple indicators that perform as well as PSI should be considered in CAP. CURB-65 is a simple and widely used severity scoring system for CAP. ${ }^{2}$ However, these scoring systems have some weak points. First, among older patients, it is difficult for clinicians to evaluate a change in mental status due to pneumonia. ${ }^{4}$ Second, these scoring systems can underestimate the potential severity of CAP in young patients. ${ }^{23}$

Of the laboratory biomarkers, some reports indicate that several serum markers such as procalcitonin, ${ }^{8-10,24} \mathrm{D}$-dimer, ${ }^{25}$

Table 6 Multivariate analysis for intensive care requirement

\begin{tabular}{lll}
\hline & OR $(95 \% \mathbf{C I})$ & P value \\
\hline Age & $1.02(0.95-1.10)$ & 0.558 \\
Coexisting illness & $1.72(0.57-5.13)$ & 0.333 \\
PSI class & $5.35(1.90-15.06)$ & 0.002 \\
CURB-65 & $2.37(1.26-4.45)$ & 0.007 \\
Sodium & $1.03(0.96-1.10)$ & 0.393 \\
Blood urea nitrogen & $1.04(0.99-1.08)$ & 0.063 \\
Albumin & $0.40(0.12-1.39)$ & 0.149 \\
B/A ratio & $1.27(1.09-1.47)$ & 0.002 \\
\hline
\end{tabular}

Abbreviations: $\mathrm{Cl}$, confidence interval; OR, odds ratio; PSI, Pneumonia Severity Index; B/A ratio, blood urea nitrogen to serum albumin ratio. cortisol, ${ }^{26} \mathrm{~B}$-type natriuretic peptide, ${ }^{27}$ and mid-regional proatrial natriuretic peptide ${ }^{28}$ correlate well with mortality and severity of CAP. However, use of these parameters routinely in patients with CAP is difficult because of cost or the retrospective nature of results. In our present study, we found a significant and independent positive correlation between $\mathrm{B} / \mathrm{A}$ ratio and mortality or severity of CAP. Both serum biochemical markers, ie, blood urea nitrogen and albumin, are commonly used and can be measured quickly. Thus, our study suggests that the $\mathrm{B} / \mathrm{A}$ ratio on admission

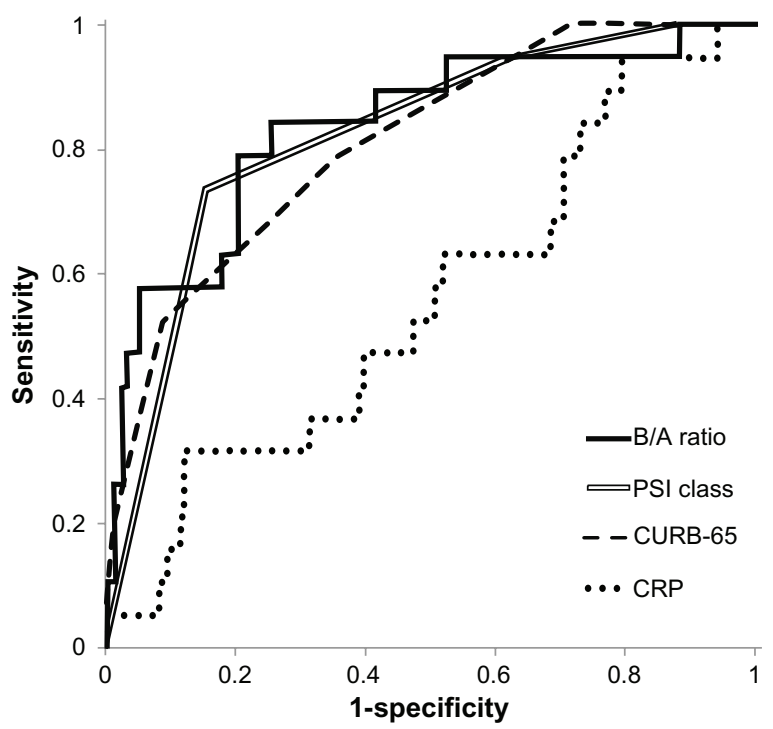

Figure I Analysis of receiver-operating characteristics curve for predicting mortality. The area under the curve was 0.83 for B/A ratio, 0.82 for PSI class, 0.81 for CURB-65, and 0.55 for CRP.

Abbreviations: B/A ratio, blood urea nitrogen to serum albumin ratio; PSI, Pneumonia severity index; CRP, C-reactive protein. 


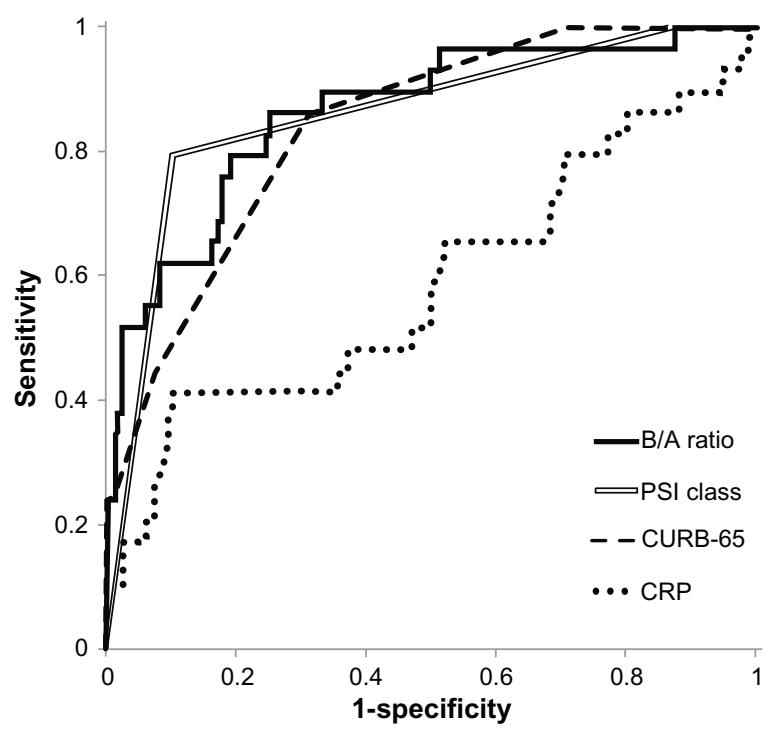

Figure 2 Analysis of receiver-operating characteristics curve for predicting need for intensive care. The area under the curve was 0.86 for B/A ratio, 0.86 for PSI class, 0.84 for CURB-65, and 0.58 for CRP.

Abbreviations: B/A ratio, blood urea nitrogen to serum albumin ratio; PSI, Pneumonia severity index; CRP, C-reactive protein.

can be a rapid, simple, and reliable prognostic and severity indicator for CAP.

C-reactive protein is an acute phase protein synthesized in the liver in response to inflammation induced by various causes ${ }^{29}$ and is widely used to evaluate the strength of the systemic inflammatory response. Chalmers et al showed that low initial serum C-reactive protein levels indicated a good prognosis in $\mathrm{CAP}^{7}$ However, several studies have shown that serum C-reactive protein levels on admission have little predictive value for mortality or severity of CAP, which is consistent with our study. ${ }^{10,30}$ Instead of the initial serum C-reactive protein level at presentation, the subsequent decline in serum C-reactive protein level after admission has a more significant relationship with clinical outcome in patients with

Table 7 Predictive validity of different cutoff values for mortality and intensive care requirement

\begin{tabular}{cllll}
\hline B/A ratio & $\begin{array}{l}\text { Sensitivity } \\
\text { (\%) }\end{array}$ & $\begin{array}{l}\text { Specificity } \\
\text { (\%) }\end{array}$ & $\begin{array}{l}\text { PPV } \\
\text { (\%) }\end{array}$ & $\begin{array}{l}\text { NPV } \\
\text { (\%) }\end{array}$ \\
\hline Mortality & & & & \\
$>7.5 \mathrm{mg} / \mathrm{g}$ & 78.9 & 75.6 & 28.3 & 96.7 \\
$>10.0 \mathrm{mg} / \mathrm{g}$ & 57.9 & 88.5 & 37.9 & 94.5 \\
$>12.5 \mathrm{mg} / \mathrm{g}$ & 52.6 & 94.9 & 55.6 & 94.3 \\
$>15.0 \mathrm{mg} / \mathrm{g}$ & 42.1 & 97.4 & 66.7 & 93.3 \\
Intensive care requirement & & & \\
$>7.5 \mathrm{mg} / \mathrm{g}$ & 79.3 & 79.5 & 43.4 & 95.1 \\
$>10.0 \mathrm{mg} / \mathrm{g}$ & 58.6 & 91.8 & 58.6 & 91.8 \\
$>12.5 \mathrm{mg} / \mathrm{g}$ & 48.3 & 97.3 & 77.8 & 90.4 \\
$>15.0 \mathrm{mg} / \mathrm{g}$ & 34.5 & 98.6 & 83.3 & 88.3 \\
\hline
\end{tabular}

Abbreviations: B/A ratio, blood urea nitrogen to serum albumin ratio; PPV, positive predictive value; NPV, negative predictive value.
CAP. ${ }^{5,6,31}$ Coelho et al showed that a high value of day 3 serum C-reactive protein level (and not initial C-reactive protein level) indicated a high mortality rate in severe CAP because it indicates treatment failure. ${ }^{6}$ Thus, in conclusion, the serum C-reactive protein level reflects the strength of the inflammatory response rather than the general condition of the patient. This parameter differs greatly from the $\mathrm{B} / \mathrm{A}$ ratio. Therefore, it is difficult to predict the mortality or severity of CAP by evaluating the serum C-reactive protein level only once.

We should mention that our current study has several limitations. First, this study cohort included a limited number of patients because it was a single-center, one-year, prospective observational study. To demonstrate the clinical significance of the $\mathrm{B} / \mathrm{A}$ ratio on admission for $\mathrm{CAP}$, additional studies including large numbers of patients are needed. Second, most of our study cohort were of advanced age. Therefore, our mortality rate may be higher compared with other earlier CAP studies. Although age was not an independent factor associated with mortality or need for intensive care by multivariate analysis, to evaluate the clinical significance of $\mathrm{B} / \mathrm{A}$ ratio on admission in CAP, additional studies including younger patients with CAP are needed. Third, we did not measure the serum procalcitonin level, which is reported to be a useful predictive prognostic biomarker in CAP. In earlier studies of serum procalcitonin levels on admission, the values of the area under the receiver operating characteristics curve for mortality of CAP ranged from 0.60 to $0.82 .{ }^{8,9,32,33}$ In contrast, our current study of the $\mathrm{B} / \mathrm{A}$ ratio on admission showed that the value of this curve for mortality within 28 days from admission was 0.83 . Although it is difficult to compare different populations, the $\mathrm{B} / \mathrm{A}$ ratio on admission seems to be comparable with the serum procalcitonin level in its ability to predict mortality from CAP.

In conclusion, the $\mathrm{B} / \mathrm{A}$ ratio on admission is a simple but reliable predictor of severity and mortality from CAP. A higher $\mathrm{B} / \mathrm{A}$ ratio on admission predicts a high mortality rate and a high probability of a need for intensive care in patients with CAP.

\section{Disclosure}

The authors report no conflicts of interest in this work.

\section{References}

1. Fine MJ, Auble TE, Yealy DM, et al. A prediction rule to identify low-risk patients with community-acquired pneumonia. $N$ Engl J Med. 1997;336:243-250.

2. Lim WS, van der Eerden MM, Laing R, et al. Defining community acquired pneumonia severity on presentation to hospital: an international derivation and validation study. Thorax. 2003;58: $377-382$ 
3. Rudolph JL, Zanin NM, Jones RN, et al. Hospitalization in communitydwelling persons with Alzheimer's disease: frequency and causes. JAm Geriatr Soc. 2010;58:1542-1548.

4. Shah BA, Ahmed W, Dhobi GN, Shan NN, Khursheed SQ, Hag I. Validity of pneumonia severity index and CURB-65 severity scoring systems in community acquired pneumonia in an Indian setting. Indian J Chest Dis Allied Sci. 2010;52:9-17.

5. Smith RP, Lipworth BJ, Cree IA, Spiers EM, Winter JH. C-reactive protein. A clinical marker in community-acquired pneumonia. Chest. 1995;108:1288-1291.

6. Coelho L, Póvoa P, Almeida E, et al. Usefulness of C-reactive protein in monitoring the severe community-acquired pneumonia clinical course. Crit Care. 2007;11:R92.

7. Chalmers JD, Singanayagam A, Hill AT. C-reactive protein is an independent predictor of severity in community-acquired pneumonia. Am J Med. 2008;121:219-225

8. Boussekey N, Leroy O, Georges H, Devos P, d'Escrivan T, Guery B. Diagnostic and prognostic values of admission procalcitonin levels in community-acquired pneumonia in an intensive care unit. Infection 2005;33:257-263.

9. Masiá M, Gutiérrez F, Shum C, et al. Usefulness of procalcitonin levels in community-acquired pneumonia according to the patients outcome research team pneumonia severity index. Chest. 2005;128 2223-2229.

10. Krüger S, Ewig S, Marre R, et al. Procalcitonin predicts patients at low risk of death from community-acquired pneumonia across all CRB-65 classes. Eur Respir J. 2008;31:349-355.

11. Schuetz P, Suter-Widmer I, Chaudri A, et al. Prognostic value of procalcitonin in community-acquired pneumonia. Eur Respir J. 2011; 37:384-392.

12. Farr BM, Sloman AJ, Fisch MJ. Predicting death in patients hospitalized for community-acquired pneumonia. Ann Intern Med. 1991; 115:428-436.

13. Raz R, Dyachenko P, Levy Y, Flatau E, Reichman N. A predictive model for the management of community-acquired pneumonia. Infection. 2003;31:3-8.

14. Potgieter PD, Hammond JM. The intensive care management, mortality and prognostic indicators in severe community-acquired pneumococcal pneumonia. Intensive Care Med. 1996;22:1301-1306.

15. Lee JH, Kim J, Kim K, et al. Albumin and C-reactive protein have prognostic significance in patients with community-acquired pneumonia. J Crit Care. 2011;26:287-294.

16. Nicholson JP, Wolmarans MR, Park GR. The role of albumin in critical illness. Br J Anaesth. 2000;85:599-610.

17. Hedlund JU, Hansson LO, Ortqvist AB. Hypoalbuminemia in hospitalized patients with community-acquired pneumonia. Arch Intern Med. 1995;155:1438-1442.

18. Al-Shaiba R, McMillan DC, Angerson WJ, Leen E, McArdle CS, Horgan P. The relationship between hypoalbuminaemia, tumour volume and the systemic inflammatory response in patients with colorectal liver metastases. Br J Cancer. 2004;91:205-207.
19. Moshage HJ, Janssen JA, Franssen JH, Hafkensheid JC, Yap SH. Study of the molecular mechanism of decreased liver synthesis of albumin in inflammation. J Clin Invest. 1987;79:1635-1641.

20. Woodford-Williams E. Respiratory tract disease. Diagnosis and management of pneumonia in the aged. Br Med J. 1966;1:467-470.

21. Kasper DL, Fauci AS, Longo DL, editors. Harrison's Principles of Internal Medicine. 16th ed. New York, NY: McGraw-Hill Professional; 2004.

22. Singanayagam A, Chalmers JD, Hill AT. Severity assessment in community acquired pneumonia: a review. QJM. 2009;102:379-388.

23. Chalmers JD, Singanayagam A, Hill AT. Predicting the need for mechanical ventilation and/or inotropic support for young adults admitted to the hospital with community-acquired pneumonia. Clin Infect Dis. 2008;47:1571-1574.

24. Müller B, Harbarth S, Stolz D, et al. Diagnostic and prognostic accuracy of clinical and laboratory parameters in community-acquired pneumonia. BMC Infect Dis. 2007;7:10.

25. Querol-Ribelles JM, Tenias JM, Grau E, et al. Plasma d-dimer levels correlate with outcomes in patients with community-acquired pneumonia. Chest. 2004;126:1087-1092.

26. Christ-Crain M, Stolz D, Jutla S, et al. Free and total cortisol levels as predictors of severity and outcome in community-acquired pneumonia. Am J Respir Crit Care Med. 2007;176:913-920.

27. Christ-Crain M, Breidthardt T, Stolz D, et al. Use of B-type natriuretic peptide in the risk stratification of community-acquired pneumonia. J Intern Med. 2008;264:166-176.

28. Masiá M, Papassotiriou J, Morgenthaler NG, et al. Midregional proA-type natriuretic peptide and carboxy-terminal provasopressin may predict prognosis in community-acquired pneumonia. Clin Chem. 2007;53:2193-2201.

29. Castell JV, Gómez-Lechón MJ, David M, et al. Acute-phase response of human hepatocytes: regulation of acute-phase protein synthesis by interleukin-6. Hepatology. 1990;12:1179-1186.

30. Thiem U, Niklaus D, Sehlhoff B, et al. C-reactive protein, severity of pneumonia and mortality in elderly, hospitalised patients with community-acquired pneumonia. Age Ageing. 2009;38:693-697.

31. Bruns AH, Oosterheert JJ, Hak E, et al. Usefulness of consecutive C-reactive protein measurements in follow-up of severe communityacquired pneumonia. Eur Respir J. 2008;32:726-732.

32. Huang DT, Angus DC, Kellum JA, et al. Midregional proadrenomedullin as a prognostic tool in community-acquired pneumonia. Chest. 2009; 136:823-831.

33. Horie M, Ugajin M, Suzuki M, et al. Diagnostic and prognostic value of procalcitonin in community-acquired pneumonia. Am J Med Sci. 2012; $343: 30-35$.
International Journal of General Medicine

\section{Publish your work in this journal}

The International Journal of General Medicine is an international, peer-reviewed open-access journal that focuses on general and internal medicine, pathogenesis, epidemiology, diagnosis, monitoring and treatment protocols. The journal is characterized by the rapid reporting of reviews, original research and clinical studies across all disease areas.

\section{Dovepress}

A key focus is the elucidation of disease processes and management protocols resulting in improved outcomes for the patient.The manuscript management system is completely online and includes a very quick and fair peer-review system. Visit http://www.dovepress.com/ testimonials.php to read real quotes from published authors. 